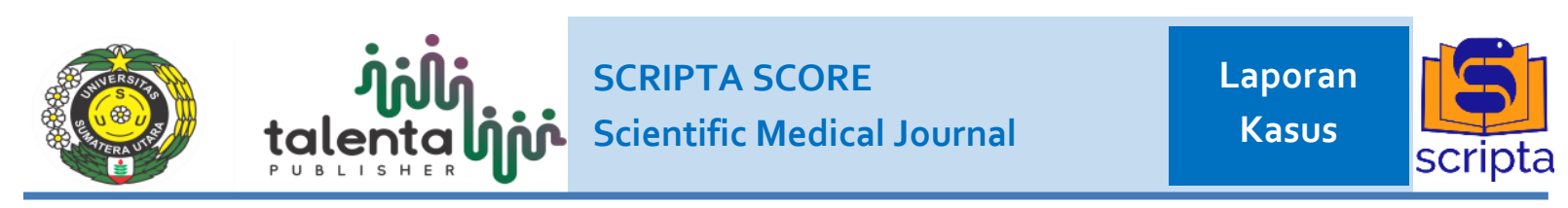

\title{
Stroke Large Vessel Occlusion pada Serologi COVID-19 Positif
}

\author{
Wilson Saputra Wijaya ${ }^{1}$, Mohammad Ridho Devantoro ${ }^{2}$, Hayyu Ari Anggriani ${ }^{2}$ \\ ${ }^{1}$ Rumah Sakit Umum Daerah Lawang, Kabupaten Malang \\ ${ }^{2}$ Fakultas Kedokteran, Universitas Trisakti, Jakarta
}

\begin{abstract}
ABSTRAK
Pada Desember 2019, severe acute respiratory syndrome coronavirus 2 (SARS-CoV-2) muncul dan memicu COVID-19 di Wuhan, Cina. Dari 329 kasus COVID-19, jenis stroke tersering berupa large vessel occlusion/LVO (31,7\%) dibanding small vessel $(15,3 \%)$. Seorang pria berusia 73 tahun datang dengan kelemahan pada sisi kiri badan sejak sehari sebelumnya setelah bertani. Awalnya kaki kiri dirasa lemas, sehingga jalannya pincang, lalu tangan kiri tampak menekuk dan tidak dapat diluruskan. Kepala dirasa nyeri berdenyut pada seluruh kepala. Bicara pasien pelo sejak kemarin dan bila minum, pasien tersedak. Aktivitasnya selama ini hanya bertani di dekat rumah dan mengaku tidak ada kontak dengan orang demam atau batuk-pilek. Dia memiliki riwayat hipertensi dan sudah mengonsumsi Candesartan 8 mg setiap pagi. Pemeriksaan fisik didapatkan tekanan darah $152 / 78 \mathrm{mmHg}$, laju nadi 58 kali per menit, laju pernapasan 20 kali per menit, temperatur $36,8{ }^{\circ} \mathrm{C}$, dan saturasi oksigen $99 \%$ dengan udara ruangan. Pada pemeriksaan fisik tampak parese N. VII, X, XII sinistra. Kekuatan otot pada tangan kiri dan kaki kiri sebesar 2 dari 5, sementara yang lainnya normal. Gerakan bola mata masih dapat dilakukan, namun kedua mata sering deviasi ke arah kanan. Pada pemeriksaan penunjang didapatkan hasil gula darah sewaktu, ureum kreatinin darah, dan elektrolit normal. Foto thorax hari pertama tampak kalsifikasi pada aorta, tidak ada infiltrate dan pada hari keempat tampak infiltrat hingga ke perifer pada kedua lapang paru. Pasien ini didiagnosis LVO akibat infeksi akut dan koagulopati COVID-19.
\end{abstract}

Kata Kunci: COVID-19, koagulopati, large vessel occlusion

\begin{abstract}
In December 2019, severe acute respiratory syndrome coronavirus 2 (SARS-CoV-2) appeared and caused COVID-19 in Wuhan, China. Of the 329 cases of COVID-19, the most common type of stroke was large vessel occlusion/LVO (31.7\%) compared to small vessels (15.3\%). A 73 year old man came in with weakness on the left side of his body since the day before after farming. Initially, the left leg felt limp, so the walk was limping, then the left hand seemed to be bent and could not be straightened. The head feels throbbing pain in the whole head. He had dysarthria since yesterday and when drinking, the patient chokes. His activity so far has only been farming near his house and he said there was no contact with people with fever or colds. He has a history of hypertension and is already taking Candesartan $8 \mathrm{mg}$ every morning. Physical examination showed a blood pressure of 152/78 $\mathrm{mmHg}$, pulse rate of 58 times per minute, respiratory rate of 20 times per minute, temperature of $36.8{ }^{\circ} \mathrm{C}$, and $99 \%$ oxygen saturation with room air. Physical examination showed paralysis of seventh, tenth, and twelfth left cranial nerve. The muscle strength of the left hand and left leg is 2 out of 5, while the rest is normal. Eyeball movement is still possible, but both eyes often deviate to the right. Investigations for the results of random blood sugar, blood creatinine urea, and electrolytes were normal. The first day of chest X-ray showed calcification in the aorta and no infiltrate. On the fourth day, there were infiltrates to the periphery in both lung fields. This patient was diagnosed with LVO with acute infection and coagulopathy of COVID19.
\end{abstract}

Keywords: coagulopathy, COVID-19, large vessel occlusion

Received [24 Sep 2020] | Revised [4 Jan 2021] | Accepted [10 Jan 2021] 


\section{PENDAHULUAN}

Pada Desember 2019, severe acute respiratory syndrome coronavirus 2 (SARS-CoV-2) muncul dan memicu COVID-19 di Wuhan, Cina. Semenjak itu, penyakit ini menjadi pandemi global salah satunya Indonesia, dengan total lebih dari 200 ribu kasus terkonfirmasi hingga September 2020. ${ }^{[1,2]}$ Gejala akibat COVID-19 ini bermacam-macam mulai dari demam (75-81\%), diikuti batuk (54$60 \%)$, hiposmia (25\%), sesak (23\%), hingga kerusakan organ (miokarditis, deep vein thrombosis, infark miokard, emboli paru) dan mortalitas sebesar 4-11\%. Sekitar $17 \%$ pasien perlu ventilasi noninvasif, dan $19 \%$ pasien perlu rawat ICU. Belum lama ini, COVID-19 diketahui meningkatkan risiko koagulopati, memicu trombus dan terjadi penyakit stroke. Dari 329 kasus COVID-19, jenis stroke tersering berupa large vessel occlusion/LVO $(31,7 \%)$ dibanding small vessel $(15,3 \%)$, serta memiliki risiko 2,4 kali lipat dibanding tanpa COVID-19 $(15,3 \%){ }^{[2,3]}$

Mulai adanya kasus stroke yang berkaitan infeksi COVID-19 di Indonesia seperti yang dilaporkan Sanyasi RDLR $\mathrm{dkk}^{[4]}$, mengenai kasus stroke iskemik dengan COVID-19 positif. Maka untuk melihat hubungan stroke dengan COVID19, kami mempresentasikan laporan kasus pasien stroke LVO dengan COVID-19 sebagai faktor risiko utama.

\section{ILUSTRASI KASUS}

\section{Laporan Kasus}

Seorang pria berusia 73 tahun datang dibawa anaknya ke Unit Gawat Darurat RSUD Lawang, Malang dengan kelemahan pada sisi kiri badan sejak kemarin setelah bertani. Awalnya kaki kiri dirasa lemas, sehingga jalannya pincang, lalu tangan kiri tampak menekuk dan tidak dapat diluruskan. Kepala dirasa nyeri berdenyut pada seluruh kepala. Bicara pasien pelo sejak kemarin dengan pembicaraan yang masih sesuai namun yang diucapkan tidak jelas. Bila minum, pasien tersedak. Mual, muntah, pingsan dan kejang disangkal. Buang air besar dan kecil masih normal. Keluarga pasien menyangkal adanya demam, batuk pilek, nyeri telan atau sesak. Aktivitasnya selama ini hanya bertani di dekat rumah dan mengatakan tidak ada kontak dengan orang demam atau batuk-pilek. Dia memiliki riwayat hipertensi dan sudah mengonsumsi Candesartan $8 \mathrm{mg}$ setiap pagi. Selama ini keluarga merasa pasien masih rutin kontrol hipertensi.

Tanda vital saat masuk: tekanan darah 152/78 mmHg, laju nadi 58 kali per menit, laju pernapasan 20 kali per menit, temperatur $36,8^{\circ} \mathrm{C}$, dan saturasi oksigen 99\% dengan udara ruangan. Pada pemeriksaan fisik tampak parese saraf fasial sinistra, vagus sinistra dan saraf hipoglossus sinistra. Kekuatan otot pada tangan kiri dan kaki kiri sebesar 2 dari 5, sementara yang lainnya normal. Gerakan bola mata masih memungkinkan, namun kedua mata sering deviasi kearah kanan. Refleks patologis Babinski dan Chaddock tampak pada ekstremitas kiri. Suara nafas dinilai normal.

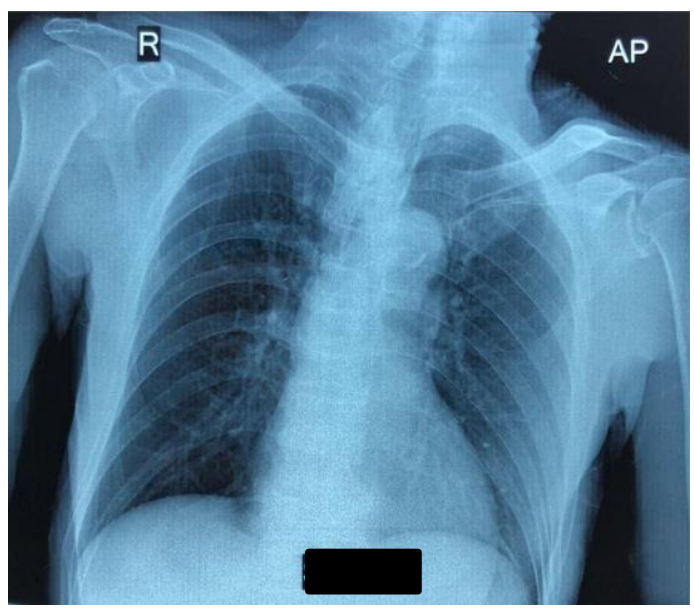

Gambar 1. Foto Toraks AP saat masuk.

\section{Interpretasi}

Pada foto toraks saat masuk (Gambar 1), tampak kalsifikasi pada aorta dan tidak ada infiltrat. Sementara pada CT scan kepala tanpa kontras saat masuk, tampak lesi hipodens (panah merah) dengan batas 
mulai tegas pada lobus fronto-temporoparietal kanan (Gambar 2). Pada hari keempat perawatan, dilakukan foto toraks ulang dimana tampak infiltrat hingga ke perifer pada kedua lapang paru (Gambar $3)$.

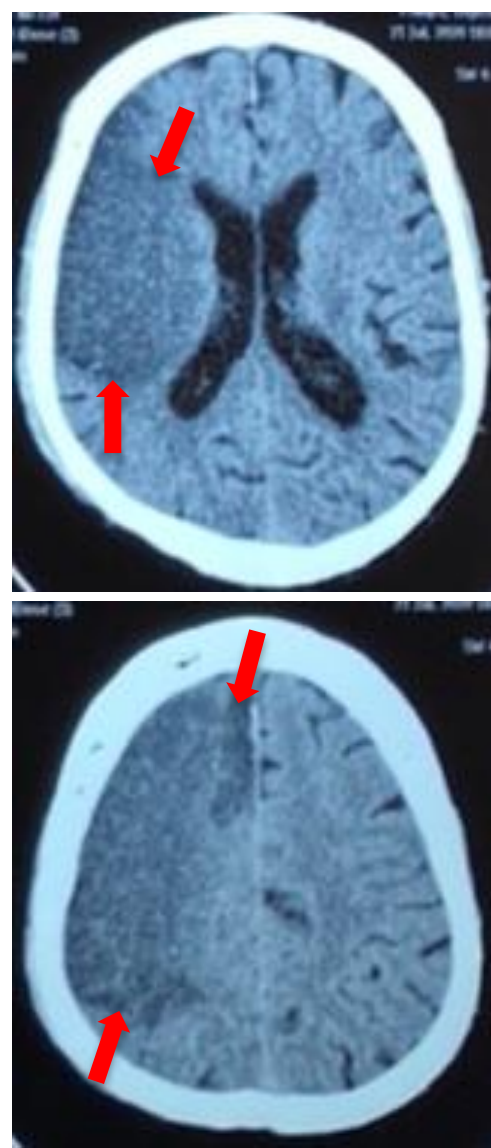

Gambar 2. CT scan kepala tanpa kontras saat masuk.

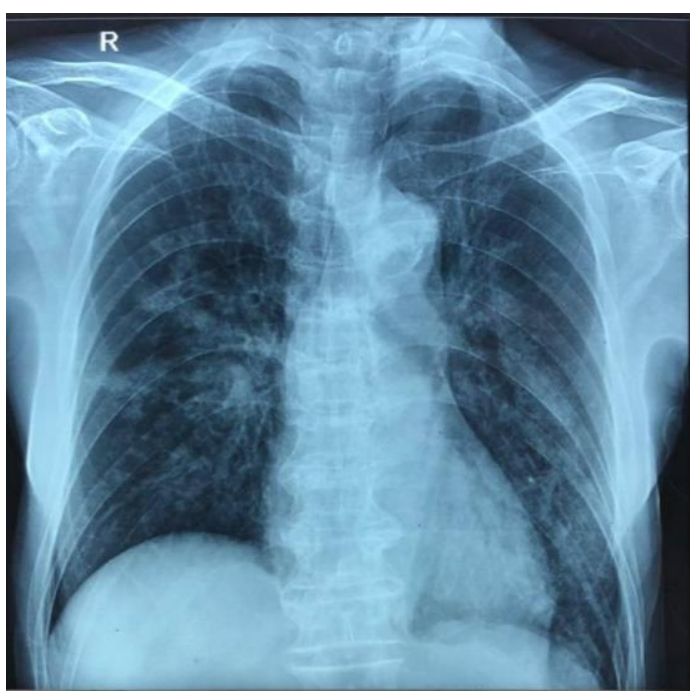

Gambar 3. Foto toraks hari keempat.
Hasil pemeriksaan darah saat masuk didapatkan leukositosis (Tabel 1), dan Neutrophyl Lymphocyte Ratio (NLR) pasien sebesar 6,83. Hasil gula darah sewaktu, ureum kreatinin darah, dan elektrolit normal. Pada hari kedua, profil lipid didapatkan LDL $141 \mathrm{mg} / \mathrm{dL}$. Hari keempat, pasien diperiksakan HbA1C. (Tabel 2).

Tabel 1. Hasil laboratorium saat admisi

\begin{tabular}{ll}
\hline Parameter & Hasil \\
\hline Hemoglobin & $15,9 \mathrm{~g} / \mathrm{dL}$ \\
Leukosit & $11.800 / \mu \mathrm{L}$ \\
Trombosit & $222.000 / \mu \mathrm{L}$ \\
Hematokrit & $46,1 \%$ \\
Eritrosit & $5,08 \times 10^{6} / \mu \mathrm{L}$ \\
Mean corpuscular volume & $90,8 \mathrm{fL}$ \\
Mean corpuscular & $31,4 \mathrm{pg}$ \\
$\quad$ hemoglobin & \\
Eosinofil & $0,7 \%$ \\
Basofil & $0,6 \%$ \\
Neutrofil & $79,9 \%$ \\
Limfosit & $11,7 \%$ \\
Monosit & $7,1 \%$ \\
Kreatinin & $0,90 \mathrm{mg} / \mathrm{dL}$ \\
Ureum & $28,31 \mathrm{mg} / \mathrm{dL}$ \\
Alanine aminotransferase & $14,04 \mathrm{U} / \mathrm{L}$ \\
Aspartate aminotransferase & $54,41 \mathrm{U} / \mathrm{L}$ \\
Natrium & $143,6 \mathrm{mmol} / \mathrm{L}$ \\
Kalium & $3,87 \mathrm{mmol} / \mathrm{L}$ \\
Klorida & $106,1 \mathrm{mmol} / \mathrm{L}$ \\
Gula darah sewaktu & $113 \mathrm{mg} / \mathrm{dL}$ \\
\hline
\end{tabular}

Tabel 2. Hasil laboratorium selama perawatan

\begin{tabular}{ll}
\hline Parameter & Hasil \\
\hline Kolesterol total & $185 \mathrm{mg} / \mathrm{dL}$ \\
Trigliserida & $65 \mathrm{mg} / \mathrm{dL}$ \\
High-density lipoprotein & $50 \mathrm{mg} / \mathrm{dL}$ \\
Low-density lipoprotein & $141 \mathrm{mg} / \mathrm{dL}$ \\
Asam urat & $5,7 \mathrm{mg} / \mathrm{dL}$ \\
HbA1c & $5,9 \%$ \\
\hline
\end{tabular}

\section{Tatalaksana}

Pasien kemudian dirawat di ruangan biasa. Pengobatan dari Spesialis Saraf selama dirawat berupa nasal kanul dengan oksigenasi $4 \mathrm{~L} / \mathrm{min}$, pemasangan selang nasogastric, pemasangan selang foley catheter, infus Ringer's Lactate 14 tetes per menit, Ranitidin 50 mg intravena (IV) 2 kali sehari, Citicoline 500 mg IV 3 kali sehari, Ketorolac 30 mg IV 2 kali sehari, 
Piracetam 3 gram IV 4 kali sehari, Amlodipin $10 \mathrm{mg}$ tablet 1 kali sehari pada pagi hari, Candesartan $8 \mathrm{mg}$ tablet $1 \mathrm{kali}$ sehari pada malam hari, Clopidogrel tablet 1 kali sehari, Aspilet tablet 1 kali sehari, dan Atorvastatin $20 \mathrm{mg}$ tablet 1 kali sehari pada malam hari.

Pada hari kedua, pasien dikonsulkan ke Spesialis Jantung. Diagnosis berdasarkan Spesialis Jantung berupa bradikardi asimptomatik, hypertensive heart disease, stroke infark dan dislipidemia. Pasien disarankan EKG basal 1-2 jam setelah Adalat Oros, Spironolakton $25 \mathrm{mg}$ tablet bila sesak, Adalat oros $30 \mathrm{mg} 2$ kali sehari, serta Amlodipin distop.

Selama hari perawatan ketiga, pasien hanya mengeluh nyeri kepala, tidak ada perburukan tanda vital, dan hanya didapati penurunan kekuatan otot pada tangan kiri dan kaki kiri menjadi 1 dari 5. Tidak ada perubahan terapi.

Hari keempat dirawat, pasien tidak bisa bicara dan tampak lemas serta gelisah. Pemeriksaan tanda vital tampak penurunan GCS menjadi E2M4Vx, tekanan darah 190/70 $\mathrm{mmHg}$, laju pernapasan 32 kali per menit, suhu $37{ }^{\circ} \mathrm{C}$, saturasi oksigen $94 \%$ dengan nasal kanul. Pemeriksaan fisik didapatkan pupil anisokor $4 \mathrm{~mm} / 2 \mathrm{~mm}$, ronkhi basah pada kedua medial paru. Nasal kanul diganti menjadi nonrebreathing mask (NRBM) dengan aliran oksigen $10 \mathrm{~L} / \mathrm{m}$. Evaluasi ulang saturasi oksigen, didapatkan masih pada 94\%. Kemudian pasien ditambahkan Furosemid 5mg/jam, mobilisasi, cek HbA1c, gula puasa, dan gula post prandial.

Tanda vital pasien memburuk, GCS E1M2Vx, tekanan darah 116/84mmHg, laju nadi 112 kali per menit, laju pernapasan 35 kali per menit, dan saturasi oksigen $87 \%$ dengan NRBM. Patensi jalur nafas pasien dengan pemasangan Guedel, Jackson Rees dengan aliran oksigen 15 $\mathrm{L} / \mathrm{m}$, dan suction. Pasien diperiksakan Rapid test COVID serta foto toraks ulang sebelum masuk ICU.
Kondisi pasien memburuk, suhu menjadi $38,8^{\circ} \mathrm{C}$, saturasi oksigen $92 \%$ dengan Jackson Rees. Hasil Rapid test pasien $\operatorname{IgG}(+), \operatorname{IgM}(-)$ dengan foto toraks AP pneumonia bilateral. Dalam waktu cepat, pasien mengalami gagal nafas hingga akhirnya henti jantung dan dinyatakan meninggal pada hari keempat perawatan pukul 23.25 WIB. Swab orofaring postmortem dilakukan sebanyak 1 kali tanggal 24 Juli 2020, dan didapatkan hasil RT-PCR COVID-19 Negatif.

\section{PEMBAHASAN}

\section{Large vessel occlusions}

Large vessel occlusions (LVO) menyebabkan sekitar 26\% hingga $46 \%$ terjadinya stroke iskemik yang disebabkan oleh penyumbatan pada sirkulasi anterior dan posterior intrakanial proksimal, yang dapat berkembang melalui 4 mekanisme yaitu oklusi akibat perkembangan aterosklerosis arteri intrakranial, emboli aterosklerotik arteri ekstrakranial atau ruptur plak yang kemudian mengakibatkan oklusi pembuluh darah intrakranial, kejadian kardioemboli seperti fibrilasi atrium yang mengakibatkan oklusi pembuluh darah intrakranial dan penyebab kriptogenik dari oklusi pembuluh darah. $^{[5,6]}$

Risiko vaskular yang teridentifikasi yaitu hipertensi, kemudian diabetes mellitus (kadar glukosa $>200 \mathrm{mg} / \mathrm{dl}$ atau uji hemoglobin terglikosiliasi $>6,4 \%$ ), lalu dislipidemia (kadar serum $>220 \mathrm{mg} / \mathrm{dl}$ saat masuk), dan yang terakhir adalah merokok. ${ }^{[7]}$ Pada pasien ini terdapat salah satu dari faktor resiko yang telah disebutkan yaitu riwayat hipertensi dan penggunaan Candesartan.

Presentasi klasik COVID-19 seperti demam, batuk kering, mialgia, kelelahan, anosmia atau diare tidak tampak pada pasien. ${ }^{[8]}$ Pasien menunjukkan gejala sistem saraf pusat berupa stroke. Laporan terbaru dari China menunjukan manifestasi neurologis pada 78 dari 214 pasien COVID-19 (36\%) yang dirawat di rumah 
sakit, diantaranya 5 pasien dengan gejala berat menunjukan gejala stroke dibanding tanpa gejala berat hanya 1 pasien. ${ }^{[9]}$ Pada studi Majidi $\mathrm{dkk}^{[10]}$, melaporkan bahwa $42 \%$ pasien yang mengalami LVO COVID-19, menunjukkan stroke sebagai gejala utama. Pada sekitar $79 \%$ dari pasien ini, didapatkan gambaran COVID-19 pada kedua apeks paru dari hasil CT angiogram leher. Sementara pada CT angiogram kepala-leher, oklusi tertinggi pada oklusi arteri karotis interna (50\%), dan kedua adalah middle cerebral artery/MCA $(42 \%)$. CT scan kepala pasien menunjukkan iskemia subakut pada lobus frontal, temporal dan parietal, dimana menandai oklusi MCA. Selain itu, 25\% pasien LVO COVID-19 berusia di bawah 50 tahun, berbeda pada non-COVID di mana LVO usia muda ( $<50$ tahun) hanya $10 \% .^{[10]}$

Pasien awalnya tidak terdapat gambaran COVID-19 pada foto toraks, namun baru terdeteksi pada hari keempat di mana terdapat infiltrat di kedua lapang paru pasien. CT scan toraks dapat dijadikan modalitas diagnosa karena sensitivitas dan spesifisitas lebih tinggi dibanding foto toraks yang sensitivitasnya 67\%. ${ }^{[1]}$ Nilai batas NLR $\geq 3,3$ dan usia $\geq 49,5$ tahun dianggap memiliki nilai prognostik tinggi, untuk menilai risiko perubahan dari gejala ringan menjadi berat dimana sekitar $46,1 \%$ pasien menjadi gejala berat dalam 6 hari. $^{[12]}$ Pasien ini memenuhi kedua nilai diatas.

Kebanyakan pasien LVO menunjukan gejala kortikal, untuk screening awal diagnosis LVO menurut Suzuki dkk ${ }^{[13]}$, di mana didapatkan mata sering melirik ke kanan (unilateral spatial neglect), sementara tidak dilakukan pertanyaan karena adanya afasia ekspresif. Nilai observasi berupa deviasi mata terpenuhi dan dapat dicurigai sebagai LVO. Hal ini dibandingkan dengan penilaian lanjutan menggunakan National Institutes of Health Stroke Scale (NIHSS) didapatkan skor 16. Hasil di antara 7-16 maka dinilai sebagai moderate stroke. ${ }^{[14]}$ Dengan menggunakan
CT scan kepala tanpa kontras, dapat dibuktikan pasien mengalami stroke LVO dengan lesi hipodens mulai berbatas tegas pada area lobus frontal, parietal dan temporal kanan. Gambaran klinis maupun radiologis pasien cocok dengan oklusi MCA akibat terkenanya area Brodmann 8 (timbul deviasi mata) dan korteks motorik primer (hemiparesis). ${ }^{[15]}$

Stroke iskemik (5\%) lebih sering ditemukan dibandingkan dengan stroke hemoragik $(0,5 \%)$ dalam sebuah laporan kasus COVID-19 dengan 221 pasien. Penderita COVID-19 yang lebih rentan terkena stroke berdasarkan data epidemiologi adalah pasien dengan usia tua, memiliki hipertensi dan level D-Dimer yang tinggi ${ }^{[16]}$. Jenis stroke tersering berupa large vessel occlusion/LVO $(31,7 \%)$ dibanding small vessel $(15,3 \%)$, serta memiliki risiko 2,4 kali lipat dibanding tanpa COVID-19 (15,3\%). ${ }^{[2]}$ Pasien memiliki dislipidemia dengan hipertensi yang dapat menjadi faktor risiko arterosklerosis. Hal ini didukung beberapa pasien dengan COVID-19 telah dilaporkan mengalami stroke lebih banyak dibandingkan tanpa COVID-19. Hal ini disebabkan oleh kardioemboli dan arterosklerosis pada pembuluh darah besar, selanjutnya diduga akibat dari proses inflamasi dan mekanisme hiperkoaguasi termasuk keberadaan antibodi antiphospolipid berkontribusi pada terjadinya peristiwa trombotik. ${ }^{[2,9]}$

\section{Mekanisme Koagulopati}

Terdapat 3 mekanisme utama yang bertanggung jawab dalam terjadinya stroke iskemik pada COVID-19 adalah keadaan hiperkoagulasi, vaskulitis, dan kardiomiopati. Lea $\mathrm{dkk}^{[17]}$ melaporkan bahwa $20-55 \%$ pasien yang dirawat di rumah sakit COVID-19 memiliki bukti laboratorium koagulopati, dengan peningkatan level D-Dimer 2 kali dari normal, perpanjangan waktu protrombin (1-3 detik diatas normal), trombositopenia ringan, dan penurunan kadar fibrinogen. Kondisi koagulopati ini ditemukan pada 
kasus-kasus stroke LVO. $^{[2]}$ Hasil lab trombosit pasien masih dalam batas normal, namun D-dimer serta prothrombin tidak diperiksa sehingga belum dapat menyingkirkan koagulopati. Patofisiologi yang mendasari keadaan hiperkoagulasi diduga berawal dari respon inflamasi yang terjadi di alveolus, yang berkontribusi pada pembentukan thrombin dan pada akhirnya membentuk bekuan fibrin, sehingga D-dimer meningkat. Invasi virus dari endotel vaskular memicu aktivasi sistem komplemen yang memulai kaskade trombotik, yang mengarah ke cedera organ dan terjadi oklusi pembuluh darah besar. ${ }^{[18]}$ Pembuluh darah tidak hanya mengalami proses peradangan oleh karena efek lokal langsung SARS-CoV-2 pada reseptor ACE-2 di endotel vaskular tetapi juga oleh respon imun sistemik terhadap pathogen (cytokine storm) seperti IL-1B, IFN, dan MCP 1 ditemukan meningkat tajam. ${ }^{[19]}$ Interaksi seluler dan inflamasi yang kompleks terlibat dalam perkembangan penyakit vaskular. Sel endotel setelah terpapar oleh sitokin mengalami perubahan fungsi yang melibatkan ekspresi gen dan sintesis de novo. Cytokine storm meningkatkan stres oksidatif, dan menurunkan eNOS (endhotelian nitric oxidase synthase) dan menginduksi apoptosis sel endotel. Sitokin adalah salah satu regulator penting dalam hematopoesis, reaksi imun, inflamasi dan vaskular. Sitokin memainkan peran penting dalam disfungsi sel endotel. Peradangan yang diakibatkan oleh cytokine storm meningkatkan trombosis dengan 2 cara yaitu secara lokal maupun sistemik. Secara sistemik, inflamasi dapat mempengaruhi aktivitas homeostatik sistemik oleh stimulasi hepatosit yang dimediasi oleh IL-6 untuk menghasilkan reaktan fase akut, termasuk didalamnya faktor koagulasi tertentu seperti peningkatan kadar fibrinogen dan inhibitor aktivator plasminogen yang menginduksi keadaan protombin. Sitokin seperti TNF- $\alpha$ mengaktifkan NF-kB (nuclear factor $k B$ ) dengan mengekspresikan molekul endotel yang menyebabkan adhesi. Disfungsi endotel mengakibatkan sintesis dan bioaktivitas vasodilator seperti NO (nitric oxide) menjadi berkurang. Perubahan ini dapat menyebabkan peningkatan produksi anion superoksida dan stres oksidatif. Anion superoksida merunkan nilai NO. sebagai akibat dari penurunan fungsi endotel ini pada akhirnya akan mengakibatkan peningkatan adhesi sel infalamasi dan proliferasi sel. Semua perubahan ini berkontribusi pada percepatan proses aterosklerotik. ${ }^{[19,20]}$

Terdapat sejumlah mekanisme keterlibatan jantung pada pasien COVID19. Salah satunya adalah invasi langsung dari virus melalui reseptor ACE2 yang terikat membran aminopeptidase yang bertindak sebagai portal dari masuknya virus yang berakhir pada disfungsi miokardial. Kerusakan jantung pada pasien COVID-19 menstimulasi sistem saraf simpatik, dan menjadi predisposisi aritmia jantung dan berujung pada kardioemboli. Dalam beberapa kasus ditemukan LVO pada usia muda ( $<50$ tahun), dengan usia termuda 33 tahun. ${ }^{[20,21]}$ Pada EKG pasien ini terdapat sinus bradikardi, namun tidak khas pada penderita COVID-19 yaitu elevasi ST-segmen, T inversi lokal, atrial premature contraction, right/left bundle branch block, nonspecific intraventricular conduction block, repolarisasi nonspesifik serta pemanjangan interval QT. ${ }^{[21]}$

\section{Diagnosa COVID-19}

Pemeriksaan swab orofaring pasien menghasilkan negatif, dengan hasil rapid test COVID-19 IgG(+) IgM(-). Hasil ini belum menyingkirkan ada tidaknya infeksi COVID-19 pada pasien. Berdasarkan beberapa penelitian mengenai lokasi dan waktu swab, serta dengan muncul gejala. Swab terbaik dilakukan dengan menggunakan sampel saluran nafas bawah dengan sensitifitas dan spesifisitas tertinggi (14 positif dari 15 sampel), sputum 75 positif dari 104 sampel, swab nasal 5 positif dari 8 sampel, dan swab faring 126 positif dari 398 sampel. Hal ini 
dikarenakan reseptor virus ACE2 terbanyak pada alveolus, sedikit pada bronkus, dan tidak ada pada faring. ${ }^{[22,23]}$ Dari penelitian $\mathrm{He} \mathrm{dkk}^{[24]}$, didapatkan penurunan drastis viral load sekitar 24 jam hingga 7 hari setelah onset gejala dan biasa negatif setelah 21 hari, sehingga dapat menunjukkan false-negative pada swab tenggorokan disertai risiko infeksiusnya menurun. Tidak ditemukan hubungan signifikan beratnya gejala dengan penurunan viral load. ${ }^{[24]}$ Sekitar $100 \%$ pasien memiliki $\operatorname{IgG}(+)$ 17-19 hari setelah onset gejala. Titer IgM dan IgG didapatkan lebih tinggi pada pasien dengan gejala berat, terutama peningkatan $\mathrm{IgG}$ signifikan. ${ }^{[25]}$ Hasil $\mathrm{IgG}(+)$ memiliki nilai positivity rate pada $\mathrm{PCR}$ negatif dan positif untuk infeksi COVID-19, 45,45\% dan 66,67\%. Untuk hasil IgG(+) dan IgM() dengan PCR negatif memiliki positivity rate $12,12 \%$. ${ }^{26]}$

Diagnosa banding untuk pneumonia pada pasien dapat dipertimbangkan sebagai hospital-acquired pneumonia dan neumonia aspirasi. Hospital-acquired pneumonia merupakan infeksi paru yang muncul selama masa perawatan di rumah sakit sekitar >48 jam. Sekitar $65,1 \%$ pasien memiliki rontgen toraks berupa infiltrat paru yang progresif atau baru. ${ }^{[27]}$ Spannella $\mathrm{dkk}^{[28]}$, menunjukkan kasus pneumonia aspirasi mirip dengan pneumonia COVID-19 karena memiliki epidemiologi usia yang sama, adanya riwayat disfagia, serta gejala sulit dinilai. Pneumonia aspirasi menyumbang 5-15\% kasus community-acquired pneumonia. Dalam penelitian tersebut, pasien sudah datang dengan demam, berbeda dengan kasus pasien. Dapat ditemukan perbedaan dalam temuan radiografi, yaitu pada pneumonia aspirasi umumnya mengenai segmen paru mengikuti gravitasi, seperti basal dari lobus inferior, sementara pada pneumonia COVID-19 umumnya ditemui bercak infiltrat multifokal pada bilateral lobus inferior terutama perifer paru. Foto toraks pasien menunjukkan bercak infiltrat bilateral lobus medius dan inferior hingga ke perifer paru. ${ }^{[28,29]}$ Maka berdasarkan progresifitas, hipoksemia persisten, hasil foto toraks pneumonia bilateral, NLR tinggi, dan $\operatorname{IgG}(+)$, diagnosa pneumonia COVID-19 belum dapat disingkirkan. Maka untuk memastikan pneumonia tersebut bukan COVID-19, dapat disarankan bronchoalveolar lavage atau sample sputum. ${ }^{[22,28]}$

\section{Tatalaksana Pasien}

Pengobatan untuk COVID-19 saat pasien masuk tidak diberikan karena tidak adanya suspek ke arah COVID-19. Leukositosis dan neutrofilia pada pasien dapat dipertimbangkan akibat stroke LVO, biasa memuncak pada 6-48 jam setelah stroke. ${ }^{[30]}$ Pemberian antibiotik untuk pencegahan pneumonia tidak dianjurkan karena beberapa penelitian menunjukkan tidak ada penurunan akhir fungsional maupun penurunan mortalitas yang signifikan. ${ }^{[31,32]}$ Dalam penelitian yang dilakukan oleh Dirican dkk, 72 pasien yang hasil tes PCR-nya positif tidak menunjukkan gejala apapun dan diikuti dalam isolasi pengobatan. Pada penelitian tersebut, 52 pasien menerima hidroksiklorokuin ditambah azithromycin, 57 pasien diberikan favipiravir, dan 30 pasien mendapatkan favipiravir plus deksametason sebagai pengobatan lini pertama. Sekitar $63,1 \%$ pasien pneumonia yang menerima hidroksiklorokuin plus azithromycin dan $28,3 \%$ pasien yang menerima favipiravir menunjukan kegagalan pengobatan. ${ }^{[31,33]}$ Namun berbeda pada studi yang dilakukan oleh de Jong dkk, didapatkan hasil pada responden yang diberikan azithromycin yang mencakup penderita dilatasi bronkus, penyumbatan mukosa, kelainan sentrilobular penebalan dinding saluran nafas, konsolidasi dan ground glass opacity mengalami peningkatan secara signifikan. Derajat perbaikan untuk semua kelainan CT berbeda secara signifikan pada non responden. ${ }^{[34]}$

Berdasarkan guideline trombosis akibat COVID-19, trombektomi menjadi 
gold standard terapi namun memiliki risiko transmisi tinggi. Pemberian antiplatelet atau kombinasi Aspilet dan Clopidogrel dapat dipertimbangkan sebagai pengganti recombinant tissue plasminogen activator (rt-PA). ${ }^{[16,35]}$ Tidak adanya emboli septik generalisata serta risiko perdarahan lebih tinggi membuat rtPA kurang disarankan. Low molecular weight heparin (LMWH) dinilai lebih efektif dibanding kombinasi Aspilet dan Clopidogrel. LMWH dapat menurunkan aktivasi jalur koagulasi tissue factordependent serta tidak adanya interaksi dengan obat antiviral seperti lopinavir/ritonavir karena aktivasi sitokrom 450, sehingga konsentrasi clopidogrel dalam darah menurun. ${ }^{[16,36]}$ Pada kondisi stroke akut, dosis loading Aspilet yang disarankan berupa 160-300 mg dilanjutkan 50-325 mg/hari, sementara dosis loading Clopidogrel $300 \mathrm{mg}$ dilanjutkan $75 \mathrm{mg} /$ hari. Dengan hasil CTscan sebagai subakut, maka tidak diberikan dosis loading. ${ }^{[37]}$

$\begin{array}{lcl} & \text { KESIMPULAN } \\ \text { LVO merupakan penyakit }\end{array}$
serebrovaskular akibat oklusi pembuluh darah besar. Mekanisme LVO dimulai dari penyempitan pembuluh darah lalu terbentuk trombosis, di mana kondisi hiperkoagulasi akibat proses inflamasi COVID-19 berkontribusi dalam pembentukan trombosis. Kasus LVO dengan COVID-19 semakin meningkat, maka pemeriksaan penunjang dilakukan untuk menilai adanya COVID-19. Meski dengan PCR dari oro-nasofaring negatif, namun dengan hasil klinis, laboratorium, radiologi yang sugestif, menjadi pertimbangan untuk tetap mencurigai adanya infeksi akut COVID-19 dan dapat memberi tatalaksana dengan cepat. Penatalaksaan pasien seperti ini harus bersifat multidisiplin, dengan fokus tidak hanya mengobati stroke namun mengendalikan kondisi hiperkoagulasi serta mengontrol infeksi pasien.

\section{SARAN}

Dengan mulai bermunculan COVID19 disertai gejala stroke, maka skrining LVO serta COVID-19 dapat dipertimbangkan pada pasien terutama pada usia muda dengan klinis LVO. Selain itu, LMWH bisa menjadi lini pertama dalam menghadapi stroke dengan COVID19.

\section{DAFTAR PUSTAKA}

[1] Kementerian Kesehatan Republik Indonesia. Situasi terkini perkembangan Coronavirus Disease (COVID-19) [Internet]; 2020 Sep 9 [cited 2020 Sep 9]. Available from: covid19.kemkes.go.id

[2] Kihira S, Schefflein J, Mahmoudi K, Rigney B, N. Delman B, Mocco $\mathrm{J}$, et al. Association of Coronavirus Disease (COVID-19) With Large Vessel Occlusion Strokes: A CaseControl Study. Am J Roentgenol. 2020;(216):1-6.

doi: 10.2214/AJR.20.23847

[3] Grant MC, Geoghegan L, Arbyn M, Mohammed Z, McGuinness L, Clarke EL, et al. The prevalence of symptoms in 24,410 adults infected by the novel coronavirus (SARSCoV-2; COVID-19): A systematic review and meta-analysis of 148 studies from 9 countries. PLoS One [Internet]. 2020;15(6 June). doi: 10.1371/journal.pone.0234765

[4] Renita Sanyasi RDL, Ardi Pramudita E. Ischemic stroke in coronavirus disease 19 (COVID-19) positive patient: a case report. J Med Sci. 2020;52(3):30-6. doi: 10.19106/JMedSciSI005203202015

[5] Rennert RC, Wali AR, Steinberg JA, Santiago-Dieppa DR, Olson SE, Pannell JS, et al. Epidemiology, Natural History, and Clinical Presentation of Large Vessel Ischemic Stroke. Clin Neurosurg. 2019;85(1):S4-8. doi: 
10.1093/neuros/nyz042

[6] Al Kasab S, Holmstedt C, Jauch E, Schrock J. Acute ischemic stroke due to large vessel occlusion. Emerg Med Rep. 2018;39(2):13-22.

[7] Vanacker P, Lambrou D, Eskandari A, Mosimann PJ, Maghraoui A, Michel P. Eligibility and predictors for acute revascularization procedures in a stroke center. Stroke. 2016;47(7):1844-9. doi: 10.1161/STROKEAHA.115.012577

[8] Wang D, Hu B, Hu C, Zhu F, Liu $\mathrm{X}$, Zhang $\mathrm{J}$, et al. Clinical Characteristics of 138 Hospitalized Patients with 2019 Novel Coronavirus-Infected Pneumonia in Wuhan, China. JAMA. 2020;323(11):1061-9. doi: 10.1001/jama.2020.1585

[9] Mao L, Jin $\mathrm{H}$, Wang $\mathrm{M}$, $\mathrm{Hu} \mathrm{Y}$, Chen S, He Q, et al. Neurologic Manifestations of Hospitalized Patients with Coronavirus Disease 2019 in Wuhan, China. JAMA Neurol. 2020;77(6):683-90. doi: 10.1001/jamaneurol.2020.1127

[10] Majidi S, Fifi JT, Ladner TR, LaraReyna J, Yaeger KA, Yim B, et al. Emergent Large Vessel Occlusion Stroke during New York City's COVID-19 Outbreak: Clinical Characteristics and Paraclinical Findings. Stroke. 2020;51:2656-63. doi:

10.1161/STROKEAHA.120.030397

[11] Cozzi D, Albanesi M, Cavigli E, Moroni C, Bindi A, Luvarà S, et al. Chest X-ray in new Coronavirus Disease 2019 (COVID-19) infection: findings and correlation with clinical outcome. Radiol Medica. 2020;125(8):730-7. doi: 10.1007/s11547-020-01232-9

[12] Yang A, Liu J, Tao W, Li H. The diagnostic and predictive role of NLR, d-NLR and PLR in COVID19 patients. Int Immunopharmacol. 2020;84:106504. doi: 10.1016/i.intimp.2020.106504
[13] Suzuki K, Nakajima N, Kunimoto K, Hatake S, Sakamoto Y, Hokama $\mathrm{H}$, et al. Emergent large vessel occlusion screen is an ideal prehospital scale to avoid missing endovascular therapy in acute stroke. Stroke. 2018;49(9):2096101. doi: 10.1161/STROKEAHA.118.022107

[14] Rost NS, Bottle A, Lee JM, Randall M, Middleton S, Shaw L, et al. Stroke severity is a crucial predictor of outcome: An international prospective validation study. J Am Heart Assoc. 2016;5(1):1-7. doi: 10.1161/JAHA.115.002433

[15] Navarro-Orozco D, Sanchez-Manso J. Neuroanatomy, middle cerebral artery [Internet]. In: StatPearls. Treasure Island: StatPearls Publishing; 2020. Available from: https://www.ncbi.nlm.nih.gov/book s/NBK526002/

[16] Qureshi AI, Abd-Allah F, Al-Senani F, Aytac E, Borhani-Haghighi A, Ciccone A, et al. Management of acute ischemic stroke in patients with COVID-19 infection: Report of an international panel. Int $\mathbf{J}$ Stroke. 2020;15(5):540-54. doi: 10.1177/1747493020923234

[17] Lee SG, Fralick M, Sholzberg M. Coagulopathy associated with COVID-19. CMAJ. 2020;192(21):E583. doi: 10.1503/cmaj.200685

[18] Varga Z, Flammer AJ, Steiger P, Haberecker M, Andermatt R, Zinkernagel AS, et al. Endothelial cell infection and endotheliitis in COVID-19. Lancet. 2020;395(10234):1417-8. doi: 10.1016/S0140-6736(20)30937-5

[19] Lax SF, Skok K, Zechner P, Kessler HH, Kaufmann N, Koelblinger C, et al. Pulmonary Arterial Thrombosis in COVID-19 With Fatal Outcome : Results From a Prospective, SingleCenter, Clinicopathologic Case Series. Ann Intern Med. 
2020;173(5):350-61.

doi: 10.7326/M20-2566

[20]

Oxley T, Mocco J, Majidi S, Kellner C, Shoirah H, Singh I, et al. Large-vessel stroke as a presenting feature of COVID-19 in the young. N Engl J Med. 2020;382(20):e60. doi: 10.1056/NEJMc2009787

[21] Mccullough S, Goyal P, Krishnan U, Choi J, Safford M, Okin P. Electrocardiographic Findings in Coronavirus Disease-19: Insights on Mortality and Underlying Myocardial Processes. J Card Fail. 2020;26(7):626-32. doi: 10.1016/j.cardfail.2020.06.005

[22] Wenling W, Yanli X, Ruqin G, Roujian L, Kai H, Guizhen W, et al. Detection of SARS-CoV-2 in different types of clinical specimens. JAMA. 2020;323(18):1843-4. doi: 10.1001/jama.2020.3786

[23] Winichakoon P, Romanee C. Negative Nasopharyngeal and Oropharyngeal Swabs Do Not. J Clin Microbiol. 2020;58(5):19-20. doi: $10.1128 / \mathrm{JCM} .00297-20$

[24] He X, Lau EHY, Wu P, Deng X, Wang J, Hao X, et al. Temporal dynamics in viral shedding and transmissibility of COVID-19. Nat Med. 2020;26(5):672-5. doi: 10.1038/s41591-020-0869-5

[25] Long QX, Liu BZ, Deng HJ, Wu GC, Deng K, Chen YK, et al. Antibody responses to SARS-CoV2 in patients with COVID-19. Nat Med. 2020;26(6):845-8. doi: 10.1038/s41591-020-0897-1

[26] Jia X, Zhang P, Tian Y, Wang J. Clinical significance of IgM and IgG test for diagnosis of highly suspected COVID-19 infection. MedRxiv. 2020; doi: $\underline{10.1101 / 2020.02 .28 .20029025}$

[27] Russell CD, Koch O, Laurenson IF, O'Shea DT, Sutherland R, Mackintosh CL. Diagnosis and features of hospital-acquired pneumonia: A retrospective cohort study. J Hosp Infect. 2016;92(3):273-9. doi: 10.1016/j.jhin.2015.11.013

[28] Spannella F, Ristori L, Giulietti F, Re S, Schiavi P, Giordano P, et al. A 95-year-old patient with unexpected coronavirus disease 2019 masked by aspiration pneumonia: A case report. J Med Case Rep. 2020;14(1):82. doi: 10.1186/s13256-020-02432-7

[29] Liang T. Handbook of COVID-19 Prevention and Treatment. Handb Covid-19, Prev Treat [Internet]. 2020;68. Available from: https://covid-19.alibabacloud.com

[30] Jickling GC, Liu DZ, Ander BP, Stamova B, Zhan X, Sharp FR. Targeting neutrophils in ischemic stroke: Translational insights from experimental studies. J Cereb Blood Flow Metab. 2015;35(6):888-901. doi: $10.1038 / \mathrm{jcbfm} .2015 .45$

[31] Kalra L, Irshad S, Hodsoll J, Simpson M, Gulliford M, Smithard $\mathrm{D}$, et al. Prophylactic antibiotics after acute stroke for reducing pneumonia in patients with dysphagia (STROKE-INF): A prospective, cluster-randomised, open-label, masked endpoint, controlled clinical trial. Lancet. 2015;386(10006):1835-44. doi: 10.1016/S0140-6736(15)00126-9

[32] Vermeij J-D, Westendorp WF, Dippel DWJ, van de Beek D, Nederkoorn PJ. Antibiotic Therapy for Preventing Infections in People With Acute Stroke. Stroke. 2018;49(5):202-3. doi: 10.1161/STROKEAHA.118.020909

[33] Dirican A, Uzar T, Karaman I, Uluisik A, Ozkaya S. Trying to Find the Answer for Two Questions in Patients with COVID-19: 1. Is pulmonary infiltrate of COVID-19 infective or inflammatory in nature (Pneumonia or Pneumonitis)? 2. Is Hydroxychloroquine plus 
Azithromycin or Favipiravir plus Dexamethasone more. MedRxiv. 2020; doi: 10.1101/2020.08.25.20181388

[34] De Jong PA, Vos R, Verleden GM, Vanaudenaerde BM, Verschakelen JA. Thin-section Computed Tomography findings before and after azithromycin treatment of neutrophilic reversible lung allograft dysfunction. Eur Radiol. 2011;21(12):2466-74. doi: 10.1007/s00330-011-2224-1

[35] Watson RA, Johnson DM, Dharia RN, Merli GJ, Doherty JU. Anticoagulant and anti-platelet therapy in the COVID-19 patient: a best practices quality initiative across a large health system. Hosp Pract. 2020;48(4):169-79. doi: 10.1080/21548331.2020.1772639

[36] Vivas D, Roldán V, Esteve-Pastor MA, Roldán I, Tello-Montoliu A, Ruiz-Nodar JM, et al. Recommendations on antithrombotic treatment during the COVID-19 pandemic. Position statement of the Working Group on Cardiovascular Thrombosis of the Spanish Society of Cardiology. Rev Esp Cardiol. 2020;73(9):749-57. doi: $10.1016 /$ j.recesp.2020.04.006

[37] Powers WJ, Rabinstein AA, Ackerson T, Adeoye OM, Bambakidis NC, Becker $\mathrm{K}$, et al. Guidelines for the early management of patients with acute ischemic stroke: 2019 update to the 2018 guidelines for the early management of acute ischemic stroke. Stroke. 2019;50:e344-418. doi:

$\underline{\text { 10.1161/STR. } 0000000000000211}$ 